Jurnal InFestasi

Vol. 14 No. 1 Juni 2018

Hal. $11-22$

\title{
Menyingkap Tabir Realitas Tax Amnesty
}

Greska Redielano Ramadan ${ }^{1}$, Nyimas Wardatul Afiqoh ${ }^{2}$

\author{
${ }^{1}$ Universitas Trunojoyo Madura, Raya Telang, Telang, Bangkalan, 69162, Jawa Timur, Indonesia \\ ${ }^{2}$ Universitas Muhammadiyah Gresik, Sumatera, Komplek Gresik Kota Baru (GKB), Gresik, 61121, Jawa Timur, \\ Indonesia
}

\author{
A R T I C L E I N F O \\ Article history: \\ Received 25 Mei 2018 \\ Revised 8 Juni 2018 \\ Accepted 17 Juni 2018 \\ Keywords: \\ Tax Amnesty, Tax Compliance, \\ phenomenology, effectivity
}

\begin{abstract}
A B S T R A C T
Tax amnesty is a shape of government's programme to increase receiptents from tax sector. Whilst, the effectiveness of these programme need to be evaluated. Data showed that from taxpayer participation and the target of tax amnesty sides, it doesn't in line with what expected. This paper addressed to reveal the reality of tax amnesty. The meaning realities of tax amnesty would parsed with peeling subject consciousness. This research would implicate to figure the meaning of tax amnesty in term to reflect taxpayer compliance phenomenon from the taxpayer and tax consultant perspectives. This study classified as qualitative research with interpretive paradigm, whilst, the research methodology used trancendental phenomenology. This research could discover a few meaning of tax amnesty. From the taxpayer and tax consultant, a few point discovered are tax amnesty is about calculating profit and loss, the existing rules ass if violated, tax amnesty is effective but there is the failed side exist, and there is unfair existing within tax amnesty.
\end{abstract}

\begin{abstract}
A B S T R A K
Tax amnesty merupakan program pemerintah dalam meningkatkan penerimaan dari sektor pajak. Seiring berlangsungnya program tersebut, efektivitasnya perlu untuk dievaluasi. Data menunjukkan bahwa dari segi partisipasi wajib pajak dan target yang dicanangkan atas program ini tidak sesuai dengan ekspektasi. Riset ini ditujukan untuk mengungkap realitas tax amnesty. Realitas makna tax amnesty akan diurai dengan mengupas kesadaran subjek melalui pengalamannya atas tax amnesty. Implikasi riset ini dapat menggambarkan pemaknaan atas tax amnesty dalam kaitannya dengan menggambarkan fenomena kepatuhan pajak dari perspektif wajib pajak dan konsultan. Riset ini merupakan riset kualitatif dengan paradigma interpretif, pendekatan yang digunakan adalah fenomenologi transendental. Riset ini berhasil mengungkap beberapa realitas makna tax amnesty is itungitungan untung rugi, peraturan terkait seolah-olah dilanggar, tax amnesty efektif tetapi terdapat sisi kegagalannya, dan adanya ketdakadilan yang hadir dengan berjalannya tax amnesty.
\end{abstract}

\section{PENDAHULUAN}

Peran pajak sebagai penerimaan negara yang paling utama sudah menjadi hal yang umum. Dalam rangka maksimalisasi penerimaan negara dari sektor pajak, pemerintah turut aktif meluncurkan berbagai kebijakan. Pada tahun 1983 Indonesia mengimplementasikan Self Assesment System (SAS) sebagai sistem pemungutan pajak (Diamastuti, 2012). Konsekuensi atas diterapkannya self assesment system yang dianut oleh Indonesia adalah ketergantungan yang tinggi terhadap kepatuhan wajib pajak (Damayanti, Sutrisno, Subekti, \& Baridwan, 2015; Diamastuti, 2012; Lai \& Choong, 2009; Tarjo \& Kusumawati, 2006). Pada kenyataannya, selama kurang lebih tiga dekade self assesment system dijalankan, kepatuhan wajib pajak yang menjadi tulang punggung keberhasilan belum menunjukkan hasil yang menggembirakan (Damayanti et al., 2015; Diamastuti, 2012).

Apabila merujuk pada beberapa hasil penelitian tentang penerapan SAS di Indonesia, 
hasilnya justru menunjukkan suatu kontradiksi antara tujuan diterapkannya sistem ini dengan kenyataannya. Dalam SAS terdapat celah yang terbuka lebar untuk dilakukannya praktik tax evasion (Darmayasa \& Rizka, 2015; Diamastuti, 2012). Badan Pusat Statistik mencatat bahwa hingga tahun 2013 jumlah penduduk Indonesia yang bekerja mencapai 93,72 orang. Berdasarkan data tersebut BPS menyimpulkan hanya sekitar 29,4\% dari total jumlah Orang Pribadi Pekerja dan berpenghasilan di Indonesia yang mendaftarkan diri atau terdaftar sebagai Wajib Pajak (WP) (Badan Pusat Statistik, 2016). Menurut Darussalam (2016) hanya sekitar 37\% WP yang melaporkan Surat Pemberitahuan (SPT), itu pun belum melihat sisi materi dari SPT-nya. Hal tersebut menunjukkan rendahnya kepatuhan wajib pajak di Indonesia jika dibandingkan dengan negara lain (Damayanti et al., 2015; Darmayasa \& Rizka, 2015; Diamastuti, 2012; Tarjo \& Kusumawati, 2006).

Upaya untuk meningkatkan penerimaan pajak terus dilakukan oleh pemerintah (Bagiada \& Darmayasa, 2016). Beberapa waktu lalu, secara resmi diluncurkan suatu kebijakan yang merupakan salah satu bentuk tax reform (reformasi perpajakan) yaitu kebijakan tax amnesty (pengampunan pajak) (Ragimun, 2016). Meskipun baru sekedar wacana yang muncul pada kisaran tahun 2015, hingga diterapkannya kebijakan ini lantas menjadi sorotan publik (Bagiada \& Darmayasa, 2016).

Isu diterbitkannya undang-undang tax amnesty ramai dibicarakan, hingga menimbulkan pro dan kontra. Beberapa pihak mengatakan bahwa tax amnesty adalah langkah yang tepat untuk mendorong penerimaan dari sektor pajak serta memaksimalkan adanya repatriasi akibat banyaknya dana wajib pajak Indonesia yang teraprkir di luar negeri. Sebagian pihak lain menilai bahwa tax amnesty hanya berkontribusi terhadap penerimaan jangka pendek dan argumen lainnya adalah bahwa Indonesia pernah mengalami kegagalan dalam penerapan tax amnesty.

Tingkat kepatuhan pajak yang rendah serta manajemen pajak yang dirasa kurang maksimal memicu munculnya inisiatif untuk berbenah, terutama dalam hal sistem dan reformasi pajak (Bagiada \& Darmayasa, 2016; Setiadi, 2016). Dengan diterapkannya kebijakan ini maka diharapkan timbul kepatuhan wajib pajak dalam memenuhi kewajiban perpajakannya. Selain hal itu, urgensi kebijakan tax amnesty juga ditujukan untuk memenuhi target penerimaan pajak jangka pendek dan jangka panjang.
Kebijakan tax amnesty ini harus terus dievaluasi efektivitasnya. Pasalnya, sejauh berjalannya tax amnesty ini, hasil yang diperoleh belum dapat dikatakan optimal. Partisipasi WP atas kebijakan ini hanya sebesar 4,8\% dari jumlah WP yang menyampaikan SPT (Primadhyta, 2017). Sementara itu, dari segi pencapaian target, dapat dikatakan jauh dari yang diharapkan. Hal ini dibuktikan dengan data dari harian cnnindonesia.com yang mencatat bahwa hasil repatriasi hanya mencapai 3\% dari target (Primadhyta, 2017).

Perlu diingat bahwa kebijakan tax amnesty pernah diterapkan di Indonesia yaitu pada tahun 1964 dan 1984. Pada saat itu penerapan kebijakan tax amnesty mengalami kegagalan. Ragimun (2016) menyatakan bahwa kegagalan kebijakan tax amnesty pada waktu itu disebabkan oleh sarana dan prasarana yang tidak mendukung. Sedangkan Tambunan dalam Bagiada \& Darmayasa (2016); Seputro, Aneswari, \& Darmayasa (2016) menambahkan bahwa tidak adanya law enforcement yang tegas pasca tax amnesty menjadi pemicu kegagalan atas diterapkannya kebijakan ini. Kita harus belajar dari kegagalan yang pernah dialami dalam penerapan tax amnesty. Payung hukum sebagai dasar penegakan aturan yang jelas diperlukan agar timbul kepastian pasca diberlakukannya tax amnesty. Sebagaimana telah terkonfirmasi dalam penelirian Alm, Mckee, \& Beck (1990) melalui eksperimennya berhasil menunjukkan bahwa rata-rata kepatuhan pajak pasca tax amnesty menurun. Namun, lain halnya ketika kebijakan ini diikuti oleh penegakan hukum yang jelas, secara agregat kepatuhan pajak meningkat.

Praktik kebijakan tax amnesty yang diberlakukan saat ini, dapat dikatakan masih belum dapat mencapai luaran yang diharapkan. Pernyataan ini didukung oleh hasil riset Farrar \& Hausserman (2016) yang memperoleh bukti empiris bahwa faktor ekstrinsik dan intrinsik yang menjadi pertimbangan WP atas keikutsertaannya dalam tax amnesty adalah untuk menghindari penalti dan mengejar manfaat aman dengan satu kali pembayaran pajak (identik dengan uang tebus atas aset dalam amnesti pajak).

Terkait dengan kajian literasi tentang tax amnesty, beberapa penelitian turut hadir sebagai sebuah jawaban atas permasalahan yang ada (Bagiada \& Darmayasa, 2016; Darmayasa, 2017; Ngadiman \& Huslin, 2015; Seputro et al., 2016; Sudarma \& Darmayasa, 2017). Pertama, penelitian Ngadiman \& Huslin (2015) tentang pengaruh 
sunset policy, tax amnesty, dan sanksi pajak terhadap kepatuhan wajib pajak. Hasil dari penelitian tersebut adalah tax amnesty berpengaruh positif terhadap kepatuhan wajib pajak. Dengan berlandaskan pada temuan dari penelitian tersebut, dapat disimpulkan bahwa dengan adanya kebijakan tax amnesty maka dapat mendongkrak angka kepatuhan wajib pajak. Akan tetapi penelitian tersebut dilakukan kurang lebih satu tahun sebelum kebijakan tax amnesty diberlakukan, yakni di tahun 2015. Sedangkan kebijakan tax amnesty diberlakukan secara resmi pada 1 Juni 2016. Oleh karena itu, penelitian ini belum menggambarkan efektivitas kebijakan tax amnesty yang sudah berjalan sampai saat ini. Selain itu, hasil penelitian tersebut juga tidak merepresentasikan kepatuhan wajib pajak saat kebijakan tax amnesty berlangsung.

Kemudian, penelitian Bagiada \& Darmayasa (2016). Di mana penelitian tersebut bertujuan untuk mendesain mekanisme tax amnesty yang dapat mewujudkan kepatuhan sukarela. Dengan menggunakan konsep Hindu Bali yaitu Catur Purusha Artha, penelitian ini mengajukan konsep kebijakan tax amnesty yang tulus (Kama). Kemudian kebijakan ini ditujukan memenuhi pendapatan negara dalam jangka pendek dan jangka panjang dengan tarif tebusan yang berlandaskan kebajikan (Dharma), untuk memperoleh Artha WP dari luar negeri. Pada akhirnya, dekonstruksi kebijakan tax amnesty diharapkan mampu mencerahkan hati seluruh WP demi mewujudkan kepatuhan sukarela. Penelitian Bagiada \& Darmayasa (2016) tersebut memang menarik untuk dikaji melalui hasil dekonstruksi tax amnesty dengan konsep Catur Purusha Artha-nya. Akan tetapi, penelitian tersebut dilakukan sebelum kebijakan tax amnesty diresmikan. Sehingga penelitian tersebut belum mampu menjadi pembangkit kepatuhan wajib pajak apabila dibandingkan dengan data yang ada.

Berikutnya, adalah penelitian Seputro et al., (2016) yang mengkaji tentang diskursus terkait isu tax amnesty. Studi ini menyajikan diskursus bahwa amnesti pajak adalah bentuk langkah pemerintah dalam memenuhi target penerimaan pajak. Namun dalam pelaksanaannya, pemerintah harus bercermin pada kegagalan di masa lalu. Payung hukum yang menaungi kebijakan ini juga harus jelas. Implikasi dari riset ini adalah memberikan wawasan positif terkait dengan berjalannya tax amnesty dan undang-undang terkait.

Senada dengan pendekatan dekonstruktif seperti penelitian yang dibahas sebelumnya, riset
Darmayasa (2017) menawarkan makna lain dari nilai wajar harta yang diungkap dalam amnesti pajak. Pemaknaan lain yang tergali dari riset ini adalah adanya makna nilai wajar aset yang diungkapkan sebagai bentuk "kuasa" pemerintah. Selain itu, pemaknaan lain adalah adanya nilai kejujuran dan ketulusan dari pengungkapan harta.

Sementara itu, masih adanya kesenjangan antara harapan diterapkannya tax amnesty dengan kenyataan yang ada cukup memotivasi kami untuk berupaya mengungkap realitas tax amnesty berdasarkan kesadaran subjek atas pengalamannya terkait dengan tax amnesty. Kami juga melihat masih sangat jarang penelitian yang menganalisis makna tax amnesty, khususnya yang secara kontekstual dilakukan di Indonesia. Berdasarkan uraian dan penjelasan tersebut, maka kami tertarik untuk meneliti tentang makna tax amnesty dari perspektif wajib pajak dan konsultan pajak. Tujuan dari penelitian ini adalah untuk mengungkap realitas tax amnesty berdasarkan perspektif wajib pajak dan pengamat isu perpajakan, dalam hal ini konsultan pajak. Reaalitas diperoleh dengan mengupas dimensi kesadaran subjek dari hasil pengalamannya atas tax amnesty. Manfaat yang dapat diberikan dari penelitian ini adalah terkait upaya pengayaan literatur dalam bidang kajian perpajakan, khususnya topik tax amnesty yang masih relatif sedikit dijumpai. Selain itu, riset ini juga bermanfaat sebagai media bagi peneliti khususnya, untuk turut serta berkontribusi memberikan argumentasi dengan menggunakan metode ilmiah. Hemat kami, riset ini juga dapat menjadi bahan bacaan untuk menambah wawasan bagi wajib pajak mengenai esensi atau makna tax amnesty, harapan kami setelah mendapat wawasan yang mendalam tersebut dapat memicu tindakan yang bijak bagi seluruh stakeholders bidang perpajakan.

Berbeda dari riset sebelumnya, penelitian ini menggunakan pendekatan kualitatif dengan paradigma interpretif. Penelitian ini lebih mengarahkan fokus penggalian makna tax amnesty dengan berdasar pada kesadaran subjek. Implikasinya dari riset ini diharapkan akan mampu menyingkap tabir realitas tax amnesty. Tidak hanya itu, upaya menggali realitas kesadaran subjek tentang kepatuhan pajak dilakukan dalam penelitian ini. Berbeda penelitian ini dengan penelitian sebelumnya adalah waktu penelitian. Penelitian ini dilakukan ketika tax amnesty telah berlangsung, tepatnya pada periode kedua. Namun, dalam perjalanannya, pengayaan kajian literasi terus dilakukan hingga pasca kebijakan ini 
berlangsung. Hal ini ditujukan sisi akademis (keilmiahan) riset ini semakin kuat.

\section{KERANGKA TEORITIS}

Asal muasal kata maupun istilah fenomenologi adalah dari bahasa Yunani, yakni dari kata phaenesthai, yang berarti menunjukkan dirinya sendiri, menampilkan. Istilah ini juga berakar pada bahasa Yunani yang hampir senada, yakni pahainomenon, yang secara harfiah berarti "gejala" atau apa yang telah menampakkan "diri" sehingga nyata bagi si pengamat (Hasbiansyah, 2008). Sebagaimana semboyan fenomenologi Edmund Husserl: Zuruck zu den sachen selbst (kembali kepada hal-hal itu sendiri). Maksudnya adalah untuk memahami apa yang sebenarnya terjadi, peneliti harus menanyakannya pada subjek yang mengalami hal itu, bukan yang lain.

Penggalian pemaknaan atas suatu objek oleh subjek melalui kesadarannya merupakan objek kajian analisis dengan fenomenologi (Conklin, 2007; Hasbiansyah, 2008; Moerer-Urdahl \& Creswell, 2004). Cara seseorang berhubungan dengan suatu hal akan sangat mempengaruhi bagaimana seseorang tersebut memaknai suatu hal. Secara epistemologis, proses fenomenologi menurut Littlejohn dan Foss (2005:38) dalam Hasbiansyah (2008) adalah proses di mana objek/peristiwa atau suatu kondisi tertentu hadir menampakkan dirinya ke dalam ke sadaran kita. Mula-mula pengetahuan berasal dari pengalaman yang kita sadari berdasarkan persepsi kita. Persepsi kita awalnya menerima suatu hal/objek/fenomena dan membiarkannya menampakkan wujudnya sebagaimana adanya. Kemudian, objek yang kita sadari dengan persepsi kita masuk ke otak dan berada dalam kesadaran murni diri kita (idea). Di sinilah terjadi interaksi antara fenomena tersebut dengan kesadaran kita. Pada akhirnya, setelah objek tersebut membuka diri dan masuk dalam kesadaran kita, kemudian akan muncul makna dari hasil interaksi tersebut.

Fenomenologi muncul akibat kejenuhan dari berbagai macam metode pemikiran yang berujung pada muara sama yaitu idealisme dan realisme Alwi (2012; 87). Idealisme atau rasionalisme mengatakan apapun yang kita ketahui itu sama dengan apa yang kita miliki dalam ruh/pikiran kita. Sehingga tidak ada realitas yang terlepas dari ruh. Bahkan ada pemikiran ekstrim yang mengatakan "yang ada hanyalah yang terfikirkan". Di sini terjadi subjektivitas absolut. Tokohtokohnya adalah Plato, Descartes, Immanuel Kant, dan lain-lain.

Berlawanan dengan pemikiran idealis, kelompok realis atau yang biasa disebut empirisme percaya bahwa ada hal-hal riil di luar kita. Kita mengetahui hal tersebut melalui persepsi/penampakan. Realitas diketahui sebagai sesuatu yang tertutup dan sangat bergantung pada manusia. Pengetahuan menurut kelompok ini berasal dari sesuatu yang riel tersebut. Tokohtokohnya yaitu Aristoteles, David Hume, Francis Bacon, dan lain-lain. Edmund Husserl sendiri, penggagas utamanya, menginginkan fenomenologi akan melahirkan ilmu yang lebih bisa bermanfaat bagi kehidupan manusia, setelah sekian lama ilmu pengetahuan mengalami krisis dan disfungsional (Hasbiansyah, 2008). Fenomenologi, kemudian berkembang sebagai semacam metode riset yang diterapkan dalam berbagai ilmu sosial, sebagai salah satu varian dalam penelitian kualitatif dalam payung paradigma interpretif.

Kamayanti (2016; 171) menyebutkan bahwa ketika penulis menggunakan pemikiran seseorang sebagai metodologi dalam tulisannya, maka penulis harus menuliskan terlebih dahulu terkait asumsi filosofis yang mendasari pemikiran tersebut. Dalam penelitian ini peneliti menggunakan fenomenologi dari Edmund Husserl. Asumsi filosofis yang mendasari fenomenologi Husserl meliputi intensionalitas kesadaran dan menafikkan dikotomi subjek objek. Intensionalitas kesadaran merupakan eksplorasi dari pengalaman seseorang secara mendalam (Conklin, 2007; Hasbiansyah, 2008; Kamayanti, 2016; 151; MoererUrdahl \& Creswell, 2004). Eksplorasi atas pengalaman tersebut berdasarkan kesadaran individu yang mengalami. Fenomenologi tidak berhenti pada analisis atau penjelasan, melainkan hingga menuju deskripsi esensi dari pengalaman tersebut. Husserl meyakini bahwa realitas tidak terpisah dari subjek. Realitas hanya dapat diungkap dengan melakukan pendekatan kepada subjek yang mengalami fenomena. Seorang fenomenolog harus memiliki sifat terbuka. Keterbukaan fenomenolog terhadap realitas yang membanjirinya membuatnya tidak mudah menjustifikasi atau menghakimi. Seorang fenomenolog menahan konsepsi pemikirannya terlebih dahulu ketika melihat realitas di lapangan. Peneliti yang menggunakan fenomenologi harus membuka diri terhadap berbagai hal yang muncul dan tersibak. Kemudian ia membiarkan segala kenampakan tersebut membanjiri pikirannya, seraya menyelaminya secara lebih mendalam, memaknai hal tersebut dengan kesadarannya. 
Stewart \& Mickunas dalam Creswell (2013; 107) menyebut hal ini sebagai pengejawantahan filsafat tanpa persangkaan. Secara epistemologis proses penundaan justifikasi disebut epoche.

Asumsi filosofis yang kedua adalah menafikkan dikotomi subjek objek (Stewart \& Mickunas dalam Creswell, 2013; 107). Realitas hanya dapat dipahami dengan dialog intersubjektif untuk mendapatkan realitas murni. Fenomenologi bukan berfokus pada pengalaman subjek, akan tetapi lebih musatkan perhatian pada bagaimana subjek mengalami pengalaman tersebut. Inilah inti dari penolakkan terhadap dikotomi subjek objek. Realitas murni hadir atas pemaknaan subjek atas suatu pengalaman (Creswell, 2013; 107).

Untuk mengeungkap makna tax amnesty dari perspektif wajib pajak dan konsultan pajak, peneliti menggunakan fenomenologi transendental. Fenomenologi transendental adalah metodologi yang paling sering digunakan dalam penelitian ilmu sosial dibanding jenis fenomenologi lainnya (Kamayanti, 2016; 151). Kata transenden di sini mengandung arti "berada di luar kemampuan manusia"; utama". Fenomenologi transendental mengupas ke "Aku"-an subjek (Kamayanti, 2016; 151). Jadi, kesadaran murni yang dimaksud Husserl adalah kesadaran mengenai "Aku". Aku yang mengalami fenomena. Jadi, fenomenologi transendental mengungkap realitas tentang " $\mathrm{Aku}$ " yang mengalami fenomena. "Aku" adalah aku yang mengalami, bukan pengalaman itu sendiri. Apa yang dialami "Aku" akan berbeda dengan yang dialami "Aku" yang lain. Labih lanjut Kamayanti mengatakan bahwa Setiap "Aku" akan membentuk persepsi, ingatan, fantasi, dan ekspektasi yang berbeda dengan "Aku" yang lain. Peneliti akan memfokuskan kedalaman analisis pada "Aku" yang mengalami fenomena untuk kemudian mendeskripsikan esensi dari sang "Aku" yang memaknai fenomena.

\section{METODE PENELITIAN}

Penelitian ini bertujuan untuk mengungkap realitas tax amnesty sebagai upaya meningkatkan kepatuhan wajib pajak menurut sudut pandang beberapa informan. Penulis nantinya akan menguraikan data-data yang diperoleh secara deskriptif dengan menggunakan kalimat-kalimat. Oleh karena itu, pendekatan penelitian ini termasuk dalam pendekatan kualitatif. Sesuai yang dikatakan oleh (Sukoharsono, 2006) bahwa penelitian kualitatif merupakan penelitian yang bermaksud untuk memahami fenomena mengenai hal yang dialami oleh subjek penelitian dengan cara deskripsi dalam bentuk kata-kata dan bahasa, pada suatu konteks khusus yang alamiah dengan memanfaatkan berbagai metode ilmiah.

Untuk penelitian dengan pendekatan kualitatif yang bertujuan mengungkap makna dibalik sebuah fenomena, dibutuhkan data dari seorang informan. Informan menjadi komponen penting dalam penelitian kualitatif. Data penelitian diperoleh dari pernyataan dan pendapat seorang informan terhadap suatu fenomena. Informan dalam penelitian ini adalah konsultan pajak setempat yakni Bapak AM. Bapak AM sudah cukup lama berprofesi sebagai konsultan pajak, kurang lebih sekitar 13 tahun. Selain berprofesi sebagai konsultan pajak, Bapak AM juga berprofesi sebagai dosen di salah satu perguruan tinggi. Selain konsultan pajak, informan lain yang ditentukan sebagai subjek penelitian adalah wajib pajak yang mengikuti tax amnesty. Wajib pajak tersebut adalah Ibu Yl. Ibu Yl adalah seorang pengusaha di bidang jasa konstruksi. Usaha yang dijalankan oleh Ibu Yl tergolong usaha yang memiliki peredaran bruto tertentu, yakni di bawah atau mencapai Rp 4,8 Miliar. Jadi, keikutsertaan Ibu Yl dalam program tax amnesty dikenakan tarif tebusan sebesar 0,5\% hingga akhir periode.

Jenis data penelitian berupa opini, sikap, pengalaman, atau karakteristik seseorang atau sekelompok orang yang menjadi subjek penelitian (responden) merupakan jenis data subjek. Data subjek juga termasuk ke dalam data primer. Hal ini karena subjek langsung memberikan ungkapanungkapan terkait suatu fenomena. Ungkapanungkapan dari informan akan menjadi unit analisis peneliti. Proses kolektivitas data dilakukan dengan wawancara mendalam. Metodologi fenomenologi sebenarnya tidak menggunakan wawancara sebagai alat koleksi data, akan tetapi menggunakan epoche (Kamayanti, 2016; 155). Kemudian untuk analisis data dalam penelitian ini dilakukan dengan menggunakan unsur-unsur dalam metodologi fenomenologi. Unsur-unsur tersebut meliputi noema, noesis, epoche/bracketing, intentional analysis, dan eidetic reduction.

\section{ANALISIS DATA DAN DISKUSI}

Penelitian ini dilakukan dengan mengerjakan setiap langkah atau tahapan-tahapan yang telah disebutkan pada bagian sebelumnya. Sebagai langkah awal, peneliti melakukan diskusi untuk menentukan informan (interviewee). Hasilnya, informan yang dipilih dalam penelitian ini sejumlah dua orang yakni wajib pajak yang mengikuti tax amnesty dan konsultan pajak di 
daerah setempat, kota Gresik. Selanjutnya, kami melakukan konfirmasi kepada informan untuk membuat janji mengenai jadwal wawancara. Setelah memperoleh kesepakatan, maka peneliti menyusun pedoman wawancara (pertanyaan dan unit analisis). Wawancara pertama dilakukan dengan informan wajib pajak yang mengikuti tax amnesty, yakni Ibu Yl. Kemudian wawancara kedua dengan konsultan pajak setempat yang menghendaki namanya untuk disebutkan dalam bentuk inisial yakni Bapak AM.

Tahapan berikutnya adalah pengolahan data. Peneliti mengerjakan transkripsi data hasil wawancara menjadi teks. Hasil transkripsi kemudian diolah lebih lanjut dengan menandai makna-makna penting. Selanjutnya peneliti mengelompokkan makna-makna tersebut ke dalam beberapa tema pembahasan. Tahap terakhir adalah menyajikan data dalam laporan hasil penelitian dan memberikan justifikasi peneliti atas fenomena yang diamati berdasarkan data yang diperoleh.

\section{DISKUSI HASIL}

\section{Fenomenologi Tax Amnesty-Efektif atau Tidak}

Berdasarkan hasil wawancara dengan informan, peneliti menemukan bahwa salah satu alasan wajib pajak mengikuti tax amnesty adalah itung-itungan untung rugi. Noema ini muncul pada ungkapan Ibu Yl "... ngikut itu kan memang \{karena ada kepentingan\} (noema)". Ibu Yl menganggap kepentingan tersebut adalah adanya keuntungan dari potensi audit kepatuhan pajak untuk laporan pajak tahun 2015 ke bawah. Hal ini terkonfirmasi melalui pernyataan beliau " $2015 \mathrm{ke}$ bawah itu $\mathrm{j}$ jelas \{tidak akan diungkit-ungkit\} (epoche) ...".

Ibu Yl merasa ikut serta dalam tax amnesty ada kalkulasi tertentu terkait dengan masalah perpajakan dalam bisnis. Ungkapan ibu Yl berikut mengkonfirmasi kalkulasi tersebut, "Kalo menurut saya sih enak ngikut ya, \{plus minusnya\} (noesis) ada gitu". Kalkulasi ini ditujukan untuk mengejar kepentingan yang terungkap sebagai noema pada pernyataan pertama. Kemudian, unsur niat yang terungkap dari pengalaman ini adalah adanya unsur aman atas keikutsertaan dalam tax amnesty. Sebagaimana pernyataan informan ibu Yl berikut, “...\{khawatir ada apa apa\} (intentional analysis) dengan perusahaannya atau orang pribadinya ya mending ngikut".

Pada titik ini, "Aku" yakni Ibu Yl merasa bahwa partisipasinya dalam tax amnesty adalah adanya "kepentingan". Kepentingan tersebut adalah terbebas dari potensi audit kepatuhan pajak untuk laporan pajak 2015 ke bawah. Lebih dalam lagi, kesadaran "Aku" melakukan ini adalah karena adanya plus minus yang merupakan kalkulasi atau hitung-hitungan untung rugi antara besarnya tebusan dengan potensi rupiah untuk utang pajak, sanksi, denda atau bunga. Pada tataran ini "Aku" juga merasa aman karena dapat menghapus dosa ketidaksesuaian laporan pajak di 2015 ke bawah.

Selain masalah besar kecilnya jumlah rupiah yang dibayarkan antara pembetulan SPT atau tax amnesty, unsur itung-itungan untung rugi juga didasari oleh pertimbangan signifikansi ketidaksesuaian laporan. Seperti yang diungkapkan Bapak AM : "kalo yang mau dibetulkan itu \{tidak signifikan\} (noema), SPT yang mau di TA itu tidak signifikan disarankan pembetulan SPT. Ngga perlu TA. Tapi kalo punya aset berupa rumah yang \{nilainya milyatan\} (epoche), TA pak ojok pembetulan. Ngono. Kalo yang berani, pembetulan".

Berdasarkan pernyataan konsultan pajak Bapak AM di atas, dapat disimpulkan bahwa tax amnesty disarankan hanya untuk ketidaksesuaian SPT yang kompleks. Perbedaan materi SPT yang tidak signifikan menurut beliau tidak perlu didaftarkan tax amnesty. Hal ini berbanding terbalik dengan apa yang disampaikan oleh DJP ketika sosialisasi tax amnesty yang sangat menyarankan untuk mengikuti tax amnesty ketika ada ketidaksesuaian dalam SPT yang dilaporkan. Bapak AM menilai akan ada \{konsekuensi lanjutan\} (noesis) ketika perbedaan yang tidak signifikan dalam SPT untuk diikutkan tax amnesty. Wajib pajak harus "total" ketika memutuskan untuk mengikuti tax amnesty. Maksudnya, tidak mengungkap informasi secara parsial pasca mengikuti tax amnesty. Karena dampaknya akan lebih besar ketika DJP mengetahui informasi yang belum diungkap sepenuhnya oleh wajib pajak. Tentu saja ini akan merugikan wajib pajak. Bahkan menurut Bapak AM ketika wajib pajak tidak mengungkapkan informasi aset sepenuhnya, maka tax amnesty sama dengan "bunuh diri" (intentional analysis). Akan tetapi, ketika wajib pajak merasa cukup untuk melakukan pembetulan SPT, maka keputusan ini dapat dibenarkan. Hal ini juga didasarkan pada aturan bahwa tax amnesty adalah hak wajib pajak. Sehingga wajib pajak tidak menyalahi aturan ketika tidak mengikuti program tersebut. "Ujung-ujungnya diakal-akali lagi ya pak?". "Lho...iya!!"

Makna itung-itungan untung rugi (Pembetulan SPT vs Tax Amnesty) menurut peneliti adalah siasat wajib pajak untuk memilih pembayaran pajak yang 
paling minimal.Tindakan ini disebut juga sebagai perencanaan pajak (tax planning). Konsep tax planning hanya akan membentuk persepsi wajib pajak untuk memilih alternatif pembayaran yang paling minimal. Prinsipnya, tidak menyalahi undang-undang. Wajib pajak di Indonesia masih belum memiliki persepsi positif mengenai pajak. Hal tersebut dibuktikan dengan itung-itungan untung rugi pembayaran pajak yang menjadi pertimbangan utama wajib pajak. Sesuai dengan pendapat Mulyani, Darminto, \& N.P (2014) bahwa masyarakat memandang pajak sebagai sesuatu yang tidak menguntungkan dan membebani seorang wajib pajak. Selain itu, karena pajak dapat mengurangi kemampuan daya beli masyarakat.

\section{Peraturan terkait seolah-olah tidak berlaku}

Berdasarkan pada Undang-undang nomor 11 tahun 2016, pengampunan pajak adalah penghapusan pajak yang seharusnya terutang, tidak dikenai sanksi pidana di bidang perpajakan, dengan cara mengungkap harta dan membayar uang tebusan sebagaimana diatur undang-undang. Wajib pajak yang selama ini dalam laporannya terdapat ketidaksesuaian, dapat memperoleh pengampunan sesuai dengan undang-undang yang berlaku (Pemerintah, 2016). Padahal,Undangundang Pajak umum, Pajak Penghasilan (PPh) dan Pajak Pertambahan Nilai (PPN) sudah sangat jelas memuat ketentuan beserta sanksinya. Dengan adanya tax amnesty peraturan-peraturan terkait yang ada sebelumnya, seolah-olah dinegasikan. Seperti keterangan informan Bapak AM : "adanya TA banyak yang..... \{peraturan yang terkait dilanggarl" (noema). Beliau melanjutkan "Jadi, aturannya PPh kalo begini, ga bayar sangsinya jelas. PPN kalo ga bayar, gini gini gini \{aturannya jelas\} (epoche).".

Berdasarkan pada pernyataan Bapak AM, peneliti mengungkap adanya inkonsistensi dengan berlakunya tax amnesty. Selama ini wajib pajak yang tidak tertib dalam memenuhi kewajiban perpajakannya akan dikenai sanksi baik berupa pidana, denda maupun bunga. Tetapi dengan adanya kebijakan pengampunan pajak, wajib pajak yang selama ini tidak patuh dapat membersihkan namanya dengan cara mengungkap harta yang belum disampaikan di SPT PPh terakhir yaitu tahun 2015. Secara otomatis, sanksi denda dan bunga serta aturan lain sebelumnya sudah tidak dihiraukan. Kebijakan ini ditujukan untuk mengungkap harta wajib pajak yang belum dilaporkan danyang selama ini terparkir di luar negeri. Selain itu, implikasi dari kebijakan ini adalah menambah database DJP sekaligus daya kejut untuk memicu peningkatan kepatuhan wajib pajak. Di tengah-tengah wawancara Bapak AM menambahkan "Sebenarnya, dengan adanya undangunndang itu \{sudah cukup\} (noesis). Ada Gijzeling, penahanan sementara. \{Tapi sayangnya itu tidak dilakukan\} (intentional analysis)...". Ketika peneliti mengonfirmasi dengan pertanyaan "berarti ga teges undang-undang?" Beliau menjawab "Lha...Iyoo"."Jadi, ya wajib pajak sing mokongmokong, dikek'i surat ga direken, itu dilakukan penahanan sementara. Tahun 2016 kemarin itu ada 4 atau 6 WP yang diGijzeling gara-gara nunggak pajak 6 milyat. Seandainya itu diterapkan bagi semua penunggak, kenek". Berdasarkan pernyataan tersebut peneliti mengungkap makna bahwa dengan peraturan perpajakan yang ada itu sebenarnya sudah cukup, dengan syarat aturan tersebut dijalankan dengan tegas.

Jadi, tidak perlu program tax amnesty. Akan tetapi, peraturan yang ada selama ini tidak diterapkan secara tegas bagi seluruh wajib pajak yang tidak patuh. Justru dengan adanya tax amnesty menunjukkanbahwa ada sisi lemah dari aturan-aturan perpajakan yang ada. Pada akhirnya, masyarakat dihimbau untuk kembali "bersih" dengan tax amnesty. Bapak AM juga menduga faktor-faktor yang menyebabkan aturan perpajakan yang ada tidak dapat dijalankan secara tegas karena kurangnya personel, resiko berat (kasus pembunuhan penagih pajak di Palembang), dan sebagainya.

\section{Tax amnesty efektif, tapi gagal}

Kebijakan tax amnesty sudah berlangsung selama dua periode, saat ini masuk periode ketiga (Januari-Maret 2017). Beberapa pihak menyebut tax amnesty saat ini berhasil. Sementara itu, sebagian pihak lain tidak sependapat. Pada penelitian ini, peneliti menemukan bahwa kebijakan tax amnesty yang telah berjalan sampai sekarang dapat dikatakan efektif, akan tetapi peneliti juga menemukan kegagalan dari tax amnesty. Tax amnesty dikatakan efektif karena menambah database wajib pajak dalam sistem DJP dan juga dari segi uang tebus untuk tambahan pendanaan negara. Kedua informan menyatakan pendapat yang sama.

Gagalnya tax amnesty terungkap berdasarkan pernyataan Bapak AM : "nah, nah, Cuman gagalnya...Aku ngomong \{gagal\} (noema) ini.". Peneliti kembali mengonfirmasi ukuran kegagalan tax amnesty. "TA sekarang gagal? Ada yang namanya...aktiva yang berupa saham, iyo!?, maksute dalam arti \{saham, itu tidak bisa di TA\} (epoche), karena 
di situ tidak bisa diuangkan. Dari seratus...seratus yo..seratus target..100\% target, yang berupa saham itu bisa jadi $80 \%$. Saya punya saham, mau saya alihkan menjadi deklarasi di dalam negeri ngga bisa, ngga bisa, ngga bisa. Ngga bisa wong saya saya \{komitmennya sama perusahaan\} (noesis).".

Kegagalan tax amnesty yang dimaksud adalah kegagalan undang-undang tax amnesty mengatasi masalah repatriasi aset berupa saham. Berdasarkan pendapat Bapak AM di atas, aktiva berupa saham tidak bisa direpatriasi karena investor sudah mempunyai komitmen dengan perusahaan. Jadi, dana investor yang berupa saham tidak dapat ditarik untuk direpatriasi, karena dalam undangundang tax amnesty aset yang direpatriasi tidak dapat dialihkan kembali ke luar negeri selama tiga tahun. Menurut Bapak AM ini yang menjadi masalah dalam kebijakan tax amnesty, khususnya untuk repatriasi aset, karena mayoritas aset WP di luar negeri banyak yang berupa saham. Hal ini juga ditengarai sebagai bentuk perlindungan terhadap "orang-orang besar" yang punya saham di luar negeri oleh Bapak AM. "Itu yang...yang memang itu \{sengaja untuk melindungi\} (intentional analysis).". "Orang gede gede yang punya saham di luar negeri".

\section{Ketidakadilan Tax Amnesty}

Apabila merujuk pada undang-undang 11 tahun 2016, dapat diketahui bahwa kebijakan pengampunan pajak menjadi hak seluruh masyarakat, baik yang mempunyai NPWP maupun yang belum. Wajib pajak dapat menggunakan atau tidak menggunakan hak untuk mengkuti program tax amnesty. Wajib pajak yang merasa dalam laporan SPT 2015 terdapat ketidaksesuaian dapat mengikuti tax amnesty. Pengampunan pajak berupa penghapusan utang pajak, sanksi, denda, dan seterusnya dapat diberikan. Sebagai gantinya wajib pajak membayar uang tebus atas aset yang belum dilaporkan dalam SPT PPh 2015 dengan tarif tertentu. Intinya, ada konsekuensi atas ketidaksesuaian laporan dan setelahnya wajib pajak mendapat pengampunan.

Peneliti kembali menemukan hal yang menarik ketika melakukan wawancara dengan Bapak AM. Sebagai konsultan pajak, beliau mempertanyakan urgensi tax amnesty bagi pejabat (pegawai negeri). Seperti ungkapan beliau : "Pertanyaan saya, nek pejabat sudah melaporkan LHKPN. Ya!?Dia melaporkan lho. Sudah lapor LHKPN, ini nyetor laporan atas harta kekayaannya.". Kemudian, peneliti melakukan konfirmasi atas pernyataan beliau dengan menanyakan apakah yang dimaksud laporan secara kontinyu. Beliau menjawab: "Lho bukan, lapor bener opo ngga tidak ada sanksi. Kalo sudah lapor ini (LHKPN) tidak perlu lapor TA. Yo \{gak adil\} (noema) dong. Saya bukan pejabat, bukan pegawai negeri, bukan pejabat BUMN, ya ga melu TA melu laporan iki wae. Itu yang gak adil. Dari ungkapan Bapak AM tersebut, dapat ditarik suatu makna bahwa tax amnesty \{adil untuk pejabat-pejabat\} (epoche), tidak adil untuk orang biasa. Pejabat dan pegawai negeri melaporkan harta kekayaannya melalui LHKPN (Laporan Hasil Kekayaan Pegawai Negeri). Sementara masyarakat biasa mengungkapkan harta yang belum dilaporkan melalui tax amnesty. Konsekuensi dari pengungkapan harta yang belum dilaporkan adalah uang tebus. Sedangkan bagi pejabat, jaminan benar tidaknya laporan harta tidak dapat dipastikan dan ttidak ada sanksi akan hal itu\} (noesis). Makna ketidakadilan tax amnesty juga dapat dikonfirmasi dari ungkapan Bapak AM : " $\{$ Lapor bener opo ngga tidak ada sanksi\} (intentional analysis). Lho iyo, kalo dia melaporkan sini (tunjuk kiri) ya laporkan sini (tunjuk kanan).". Beliau menyayangkan bahwa ketidakadilan TA yang tidak terungkap.

\section{Tax Amnesty Untuk Meningkatkan Kepatuhan Wajib Pajak \\ Tax Amnesty Bermanfaat Bagi WP}

Dengan adanya kebijakan pengampunan pajak, wajib pajak dapat melakukan "pengakuan dosa" atas ketidakpatuhannya selama ini. Tax amnesty bermanfaat bagi wajib pajak. Wajib pajak menganggap dengan mengikuti taxamnesty akan memberikan rasa aman, karena laporan tahun 2015 ke bawah tidak diungkit-ungkit lagi. Seperti yang diungkapkan Ibu Yl : "Karena ada kepentingan terus aman gitu kan ya terhadap eee pelaporan perpajakan 2015 ke bawah itu jelas tidak ada akan di ungkitungkit lagi". Menurut peneliti, setelah wajib pajak melakukan pengakuan dosa, maka wajib pajak dalam kondisi kosong-kosong (draw) dengan DJP. Kondisi ini diharapkan dapat memicu wajib pajak untuk tidak mengulangi kesalahan yang sama seperti telat membayar, lapor, atau bahkan tidak membayar atau melapor. Bahkan Ibu Yuli menyarankan untuk mengikuti tax amnesty. Pernyataan Ibu Yl : "Klo menurut saya sih enak ngikut ya".

\section{Ketegasan Dalam Menjalankan Aturan}

Pemerintah sebenarnya sudah mempunyai dasar yang kuat dalam rangka maksimalisasi penerimaan pajak. Dasar tersebut adalah undangundang perpajakan (KUP, PPh, PPN, dsb). Tinggal 
bagaimana pemerintah menjalankannya dengan tegas. Fenomena gijzeling yang belum diterapkan sepenuhnya untuk seluruh wajib pajak yang tidak patuh adalah salah satu contoh kurangnya penegakkan aturan perpajakan yang ada. Kurangnya ketegasan dalam menjalankan aturan pada akirnya diatasi dengan adanya kebijakan pengampunan pajak. Pernyataan Bapak AM : "Sebenarnya, dengan adanya undang-unndang itu sudah cukup. Seandainya itu diterapkan bagi semua penunggak, kenek". Berdasarkan pada pendapat Bapak AM, dapat disimpulkan bahwa untuk dapat meningkatkan kepatuhan wajib pajak kuncinya adalah penegakkan aturan secara tegas. Jadi, wajib pajak benar-benar termotivasi untuk memenuhi kewajiban perpajakannya. Kebijakan pengampunan pajak seharusnya menjadi momentum bagi pemerintah dan wajib pajak untuk evaluasi diri.

Tuhan Tidak Menyuruh Kita Untuk Mutlak Benar, Tetapi Tuhan Hanya Menyuruh Untuk Berupaya Benar.

Ungkapan filosofis di atas menurut peneliti dapat memberikan refleksi bagi wajib pajak. Maksud dari ungkapan tersebut adalah dalam konteks agama, sulit untuk mencari kebenaran mutlak. Kebenaran absolut hanyalah milik Tuhan Yang Maha Esa. Manusia sebagai makhluk Tuhan wajib untuk terus berupaya mencari kebenaran. Telaah secara filosofis dalam buku-buku filsafat seperti yang dikemukakan Alwi, (2012; 45) bahwa Tuhan telah memberikan konfirmasi-konfirmasi mengenai apa-apa yang dikatakan benar dan salah. Kita hanya dituntut untuk mengikuti prosedur kebenaran tersebut dan terus berupaya mencari kebenaran. Sejalan dengan hal itu, kita dapat merefleksikan ungkapan filosofis tersebut dalam konteks perpajakan. Banyak sekali poin-poin, penekanan, klausul, detail, dan teknis dalam aturan perpajakan. Sebagai contoh kebijakan tax amnesty. Undang-undang, Peraturan Menteri Keuangan, dan Surat Edaran memuat hal-hal yang terkadang membingungkan, sulit dipahami. Bahkan tidak jarang ada peraturan yang sifatnya abu-abu (grey area), dan juga multi tafsir. Menurut pendapat wajib pajak Ibu Yuli yang mengikuti tax amnesty, masih banyak WP yang belum paham mengenai mekanisme tax amnesty. "Iya belum tentu ngerti. Kadang yang dijelaskankan secara umum saja untuk detail pelaporannya seperti apakan tidak disampaikan di situ. Cuma sosialisasi manfaat, seperti seminar". Berdasarkan pernyataan Ibu Yl, banyak WP yang masih bertanya-tanya bagaimana mekanisme tax amnesty yang benar. Ini merupakan salah satu indikasi pelaksanaan kebijakan tax amnesty yang belum maksimal.

"Yang penting itu lapor, untuk yang kewajiban pelaporan jangan sampai telat, nggak akan ada apa$a p a^{\prime \prime}$. Berdasarkan pernyataan Ibu Yl di atas, peneliti mengungkap makna bahwa sebagai wajib pajak mengikuti aturan, prosedur, dan ketentuan perpajakan yang berlaku itu sudah cukup. Wajib pajak cukup untuk bertindak prosedural, bayar tepat waktu, lapor tepat waktu, dan informasi yang disampaikan dengan jujur. Tidak perlu takut salah, karena aturan perpajakan juga memberikan kesempatan untuk melakukan pembetulan. Menurut peneliti, wajib pajak hanya perlu bertindak wajar. Kalau salah dibetulkan, kalau tidak paham segera mencari informasi, dan tetap dalam rambu-rambu yang ada. Jadi, inilah refleksi ungkapan filosofis Tuhan tidak menyuruh kita mutlak benar, tetapi Tuhan hanya menyuruh kita untuk berupaya benar.

\section{Suatu Kepatuhan Sukarela}

Dengan menggunakan konsep Hindu Bali yaitu Catur Purusha Artha Bagiada \& Darmayasa (2016) mencoba mendekonstruksi konsep kebijakan pengampunan pajak. Dekonstruksi konsep kebijakan tax amnesty tersebut diharapkan mampu mencerahkan hati seluruh WP demi mewujudkan kepatuhan sukarela. Konsep tersebut menarik, karena mengangkat nilai-nilai budaya lokal untuk mendekonstruksi tax amnesty. Namun, hemat kami, konsep tersebut tak ubahnya hanya dalam bentuk konsep atau bersifat teoritis.

Pada penelitian ini, peneliti mengungkap upaya untuk menciptakan suatu kepatuhan sukarela yang bersifat praktis dan aplikatif. “WP seharusnya dapat patuh dengan sukarela walaupun sudah mengikuti Tax Amnesty" pendapat dari Ibu Yl. "Setiap harta yang di ungkap kan setiap 6 bulan sekali kan harus di laporkan juga. Jd nggak sembarangan sudah lapor tax amnesty terus bebas gtu ndak juga." lanjut beliau. Senada dengan yang diungkapkan Ibu Yuli, Bapak AM selaku konsultan pajak mendukung kebijakan tax amnesty, meskipun masih banyak kekurangan di dalam kebijakan ini. Ketika peneliti mengonfirmasi apakah tax amnesty dapat meningkatkan kepatuhan wajib pajak, beliau menjawab bisa. Berikut ungkapan beliau : "Nek Aku setuju. Yaa...untuk menambah wajib pajak. Jadi, menambah masyarakat \{wedi\} (noema) pajak. Wedi!! Wedi!!. Berdasarkan pernyataan dari kedua informan, makna tax amnesty dapat meningkatkan kepatuhan wajib pajak dalam hal ini adalah takut. Hal tersebut dapat dilihat dari penekanan kalimat 
terus bebas gtu ndak juga dan juga Wedi!! Wedi!!

Pajak di mata masyarakat dianggap sebagai beban yang dapat mengurangi penghasilan (Mulyani et al., 2014). Masyarakat merasa dirugikan ketika harus membayar sejumlah uang untuk keperluan pajak. Padahal, pajak merupakan sumber penerimaan negara yang paling utama. Dana yang masuk dari sektor pajak digunakan untuk kepentingan umum seperti perbaikan jalan, pendidikan, pembangunan infrastruktur, fasilitas kesehatan umum, dan lain sebagainya. Begitu pentingnya pajak untuk pembangunan negara. Yang menjadi masalah, selama ini wajib pajak patuh karena takut akan sanksi denda, bunga, dan pidana. Pertanyaannya, mungkinkah menciptakan suatu kepatuhan sukarela?

"\{Negara baru bisa memberikan fasilitas yang sifatnya umum\} (epoche). Negara lain tidak, \{kontribusinya WP itu terkait masa tuanya nanti\} (noesis). Negara akan menghidupi mereka saat sudah tidak bisa bekerja, sesuai dengan kontribusinya terhadap pajak ketika masih bekerja. Contohnya di Singapura, mereka sudah sadar, untuk berlomba-lomba menarik tax dari lawan transaksinya." Ungkapan Bapak AM.

Berdasarkan pendapat Bapak AM di atas, peneliti menyimpulkan bahwa kunci untuk menciptakan kepatuhan sukarela adalah \{kesadaran dan adanya kontribusi negara kepada WP secara langsung\} (intentional analysis). Ketika WP sadar akan pentingnya pajak bagi pembangunan negara, maka WP akan memiliki rasa peduli. Karena kepedulian tersebut nantinya WP akan patuh secara sukarela. Namun apakah di Indonesia bisa menerapkan sistem seperti di Singapura dalam hal manfaat secara langsung kepada WP atas kontribusinya? Yang paling penting adalah memupuk kesadaran bahwa fasilitas negara yang selama ini dimanfaatkan, dibiayai dari penerimaan pajak. Oleh karena itu, sudah saatnya kita sadar dan peduli bahwa kontribusi pembayaran pajak kita sangat penting untuk membangun negara Indonesia.

\section{SIMPULAN}

Penelitian ini berhasil mengungkap maknamakna dari ungkapan informan terkait efektivitas tax amnesty dalam upaya meningkatkan kepatuhan wajib pajak. Berdasarkan pengelompokkan makna tax amnesty di atas, dapat disimpulkan bahwa di satu sisi tax amnesty dapat dikatakan efektif. Ukuran efektivitas tax amnesty adalah peningkatan database aset wajib pajak dan juga uang tebus yang berkontribusi menambah kas negara. Namun, di sisi lain tax amnesty juga masih kurang maksimal dan mengalami kegagalan. Tax amnesty dikatakan kurang maksimal karena wajib pajak bukan dengan kesadarannya melakukan "pengakuan dosa" atas ketidakpatuhannya selama ini. Wajib pajak justru memanfaatkan tax amnesty agar laporan yang lalu tidak diungkit-ungkit. Akan tetapi tax amnesty hanya opsi. Keputusan wajib pajak untuk ikut tax amnesty atau tidak ditentukan dari hasil itungitungan untung rugi (Pembetulan SPT vs Tax Amnesty). Kemudian, tax amnesty mengandung makna seolah-olah menegasikan peraturan pajak yang ada (KUP, PPh, PPN). Selain itu, gagalnya undang-undang dalam mengatasi kasus aktiva berupa saham yang tidak bisa direpatriasi. Yang terakhir, adanya unsur ketidakadilan tax amnesty dibandingkan dengan mekanisme LHKPN untuk pejabat dan pegawai negeri yang tidak terungkap. Ini menjadi evaluasi bagi pemerintah selaku pembuat kebijakan dan wajib pajak yang menjadi jiwa kepatuhan pajak.

Sementara itu, penelitian ini berhasil mengungkap makna tax amnesty yang dapat meningkatkan kepatuhan wajib pajak. Berdasarkan pada diskusi hasil pada bagian kedua, tax amnesty bermanfaat bagi WP. WP merasa aman dan lega ketika sudah membersihkan diri dengan mengikuti tax amnesty. Pemerintah, perlu untuk mengevaluasi penerapan aturan perpajakan yang ada. Karena berdasarkan pada pendapat informan di atas, aturan yang ada tidak diterapkan secara tegas bagi semua WP yang tidak patuh. Selanjutnya, masih banyak WP yang belum memahami mekanisme dan prosedur tax amnesty. WP juga bingung mengenai urgensi keikutsertaannya dalam tax amnesty. Akan tetapi, intinya adalah WP bertindak sesuai prosedur yang ada. Yang terakhir, WP selama ini terpaksa untuk patuh. Motivasi WP untuk patuh adalah karena takut (sanksi denda, bunga, pidana). Kepatuhan secara sukarela dapat diciptakan dengan kunci utama kesadaran WP untuk peduli, serta kesadaran Pemerintah untuk peduli terhadap WP.

Keterbatasan dalam penelitian pengumpulan data melalui wawancara yang masih relatif singkat. Hal ini berimplikasi pada terbatasnya bracketing yang berhasil ditangkap oleh peneliti. Tidak menutup kemungkinan masih terdapat maknamakna lain yang merefleksikan kesadaran subjek. Penelitian ini belum berkesempatan untuk melakukan wawancara mendalam dengan fiskus (pegawai pajak). Penelitian ini berimplikasi untuk mengungkap makna kebijakan tax amnesty yang sudah berjalan selama sekian periode, serta dengan mengacu pada keterbatasan penelitian ini, maka 
saran yang diberikan oleh peneliti adalah sebagai berikut :

1. Memperdalam pengumpulan dan analisis data untuk penelitian selanjutnya.

2. Melakukan penelitian dengan menambah informan penelitian, misalnya fiskus (pegawai pajak).

3. Mempertimbangkan pengambilan data statistik mengenai efektivitas kebijakan tax amnesty.

4. Bagi wajib pajak, hendaknya sudah mulai memupuk kesadaran untuk peduli terhadap pembangunan negara dengan cara tertib memenuhi seluruh kewajiban perpajakan dan turut serta mengawal pengelolaan dana pajak.

5. Bagi pemerintah, seyogyanya terus melakukan evaluasi terhadap tax amnesty saat ini, serta evaluasi terhadap aturanaturan perpajakan, sistem perpajakan, serta hal lain yang berkaitan. Kemudian, pemerintah seyogyanya melakukan langkah perbaikan yang kongkrit.

\section{REFERENCES}

Alm, J., Mckee, M., \& Beck, W. (1990). Amazing Grace: Tax Amnesties and Compliance. National Tax Journal, 43(1), 23-37.

Alwi, M. (2012). Islam dan Teologi Berkebenaran sebuah "Orientasi" dalam ber Agama. Bangil, Pasuruan. Bangil, Pasuruan: Oemah Boekoe. Retrieved from pendidikanpositif.blogspot.com

Bagiada, I. M., \& Darmayasa, I. N. (2016). TAX AMNESTY UPAYA MEMBANGUN KEPATUHAN SUKARELA. Simposium Nasional Akuntansi Vokasi $V, 1-24$.

Conklin, T. A. (2007). Method or madness: Phenomenology as knowledge creator. Journal of Management Inquiry, 16(3), 275-287. https://doi.org/10.1177/1056492607306023

Creswell, J. W. (2013). Penelitian Kualitatif \& Desain Riset, Memilih Di Antara Lima Pendekatan. Yogyakarta: Yogyakarta: Pustaka Pelajar.

Damayanti, T. W., Sutrisno, T., Subekti, I., \& Baridwan, Z. (2015). The Role of Taxpayer's Perception of the Government and Society to Improve Tax Compliance. Accounting and Finance Research, 4(1). https://doi.org/10.5430/afr.v4n1p180

Darmayasa, I. N. (2017). Sebagai pemaknaan lain atas nilai wajar harta amnesti pajak. Jurnal Akuntansi Multiparadigma, 8(1), 166-182.

Darmayasa, I. N., \& Rizka, Y. (2015). The ethical practice of tax consultant based on local culture. Procedia - Social and Behavioral Sciences, 211 (September), $142-148$. https://doi.org/10.1016/j.sbspro.2015.11.021

Darussalam. (2016). Urgensi Pengampunan Pajak Di
Indonesia. Jakarta: www.koran.bisnis.com. Retrieved from www.koran.bisnis.com

Diamastuti, E. (2012). Ke ( Tidak ) Patuhan Wajib Pajak: Potret Self Assessment System. Ekonomi Dan Keuangan, 20(80), 280-304.

Farrar, J., \& Hausserman, C. (2016). An Exploratory Investigation of Extrinsic and Intrinsic Motivations in Tax Amnesty Decision-Making. Journal of Tax Administration, 2(2), 47-66.

Hasbiansyah, O. (2008). Pendekatan Fenomenologi : Pengantar Praktik Penelitian dalam Ilmu Sosial dan Komunikasi. Mediator, 9(1), 163-180. https://doi.org/10.29313/mediator.v9i1.1146

Kamayanti, A. (2016). Metodologi Penelitian Kualitatif Akuntansi Pengantar Religiositas Keilmuan. Malang: Yayasan Rumah Peneleh.

Lai, M.-L., \& Choong, K.-F. (2009). Self-Assessment Tax System and Compliance Complexities: Tax Practioners' Perspectives. Oxford Business \& Economics Conference Program, 1-21.

Moerer-Urdahl, T., \& Creswell, J. W. (2004). Using Transcendental Phenomenology to Explore the "Ripple Effect" in a Leadership Mentoring Program. International Journal of Qualitative Methods, 3(2), 19-35. https://doi.org/10.1177/160940690400300202

Mulyani, S., Darminto, \& N.P, M. . W. E. (2014). Pengaruh karakteristik perusahaan, koneksi politik dan reformasi perpajakan terhadap penghindaran pajak (studi pada perusahaan manufaktur yang terdaftar di bursa efek tahun 2008-2012). Jurnal Mahasiswa Perpajakan, 2(1).

Ngadiman, \& Huslin, D. (2015). PENGARUH SUNSET POLICY , TAX AMNESTY , DAN SANKSI PAJAK TERHADAP KEPATUHAN WAJIB PAJAK ( Studi Empiris di Kantor Pelayanan Pajak Pratama Jakarta Kembangan ). Jurrnal Akuntansi, XIX(02), 225-241. Retrieved from http://journal.tarumanagara.ac.id/index.php/jakt/art icle/view/2292

Pemerintah. (2016). Undang-Undang Republik Indonesia Nomor 11 Tahun 2016 Tentang Pengampunan Pajak, (1).

Primadhyta, S. (2017). CORE: Hasil Tax Amnesty Jauh dari Ekspektasi. Jakarta: CNN Indonesia. Retrieved from https://www.cnnindonesia.com/ekonomi/20170403 103842-78-204494/core-hasil-tax-amnesty-jauhdari-ekspektasi

Ragimun. (2016). Analisis Implementasi Pengampunan Pajak (Tax Amnesty) Di Indonesia. Http://Www.Kemenkeu.Go.Id. Jakarta: Kementrian Keuangan. Jakarta: Kementerian Keuangan. Retrieved from http://www.kemenkeu.go.id

Seputro, H. Y., Aneswari, Y. R., \& Darmayasa, I. N. (2016). DISKURSUS TAX AMNESTY MELALUI RUU PENGAMPUNAN NASIONAL ( Potencial Fraud and Money Laundering 
Perspective ). Journal of Auditing, Finance, and Forensic Accounting, 04(2), 111-120.

Setiadi, A. (2016). Cakrawala Hukum Cakrawala Hukum. Cakrawala Hukum, XII(01), 95-110.

Statistik, B. P. (2016). Refleksi Tingkat Kepatuhan Wajib Pajak. Jakarta: www.pajak.go.id. Retrieved from www.pajak.go.id

Sudarma, I. M., \& Darmayasa, I. N. (2017). Does Voluntary Tax Compliance Increase After Granting Tax Amnesty? Accounting and Finance Review, 2(3), 11-17.

Sukoharsono, E. G. (2006). Alternatif Riset Kualitatif
Sains Akuntansi: Biografi, Phenomenologi, Grounded Theory, Critical Ethnografi dan Case Study. Analisis Makro Dan Mikro: Jembatan Kebijakan Ekonomi Indonesia, 230-245.

Tarjo, \& Kusumawati, I. (2006). ANALISIS PERILAKU WAJIB PAJAK ORANG PRIBADI TERHADAP PELAKSANAAN SELF ASSESSMENT SYSTEM : Jurnal Akuntansi \& Auditing Indonesia, 10(1), 101-120. 